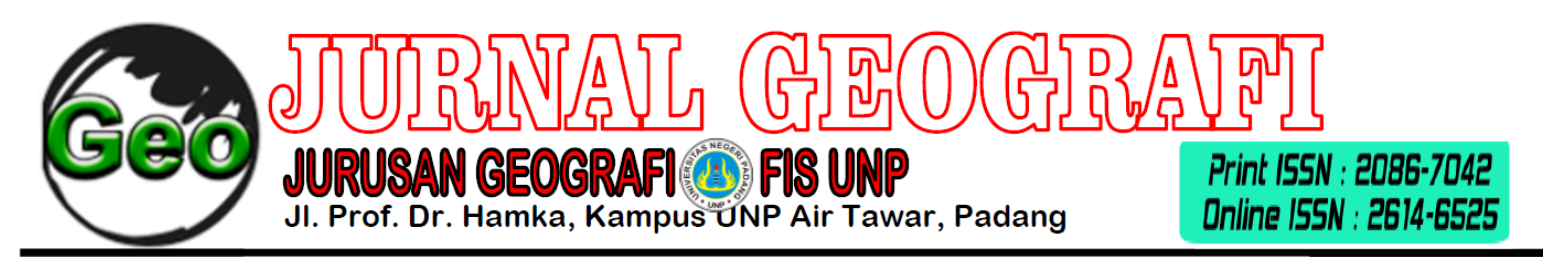

\title{
KLASIFIKASI KUALITAS PERMUKIMAN MENGGUNAKAN CITRA QUICKBIRD DI KECAMATAN MANDIANGIN KOTO SELAYAN KOTA BUKITTINGGI
}

\author{
S.R Bening Pratiwi K ${ }^{1}$, Triyatno $^{2}$, Fitriana Syahar ${ }^{2}$ \\ Program Studi Geografi, Fakultas Ilmu Sosial, Universitas Negeri Padang \\ Email : Beningpratiwi31@ gmail.com
}

\begin{abstract}
ABSTRAK
Tujuan dari penelitian ini adalah (1) mendeskripsikan parameter kualitas permukiman (2) menganalisis persebaran kualitas permukiman di Kecamatan Mandiangin Koto Selayan, (3) menguji tingkat ketelitian interpretasi Citra Quickbird. Metode yang digunakan untuk kualitas permukiman yaitu metode pengharkatan (scoring) dan tumpang susun (overlay). Uji ketelitian citra menggunakan metode confution matrix. Berdasarkan hasil penelitian memperlihatkan bahwa (1) parameter kualitas permukiman yaitu kepadatan permukiman memiliki kualitas sedang yang luasnya 120 $\mathrm{Ha}$, pola tata letak bangunan memiliki kualitas buruk yang luasnya $182 \mathrm{Ha}$, pohon pelindung permukiman memiliki kualitas buruk yang luasnya $233 \mathrm{Ha}$, lebar jalan memiliki kualitas buruk yang luasnya $207 \mathrm{Ha}$, kondisi jalan permukiman memiliki kualitas baik yang luasnya $204 \mathrm{Ha}$, dan variabel lokasi permukiman memiliki kualitas sedang yang luasnya $91 \mathrm{Ha}$, (2) persebaran kualitas pesmukiman di Kecamatan Mandiangin Koto Selayan untuk kualitas permukiman sedang memiliki luas $125 \mathrm{Ha}$, kualitas permukiman buruk memiliki luas $118 \mathrm{Ha}$. Kualitas permukiman sedang paling banyak di Kelurahan Kubu Gulai Bancah sedangkan kualitas permukiman buruk paling banyak di Kelurahan Campago Guguak Bulek, (3) uji ketelitian citra menggunakan confusion matrix menghasilkan nilai akurasi ketelitian citra yaitu 94,73 $\%$.
\end{abstract}

\section{Kunci : kualitas permukiman, penginderaan jauh, Citra Quickbird, SIG.}

\begin{abstract}
The purpose of this research are (1) describe the quality parameters of settlement, (2) analyze the distribution of quality of settlements, (3) test the accuracy of interpretation Quickbird. Methods used for the quality of settlements is scoring and overlay. Accuracy of interpretation used confusion matrix method. Based on research result show that (1) the quality parameter of the settlements is the density of the settlements has a medium quality of $120 \mathrm{Ha}$, the pattern of the building layout has a bad quality of $182 \mathrm{Ha}$, tree protective settlement has a bad quality of $233 \mathrm{Ha}$, the road width has bad quality the extent of $207 \mathrm{Ha}$, the condition of residential road has good quality which is $204 \mathrm{Ha}$, and the residential location variable has medium quality which is $91 \mathrm{Ha}$. (2) the distribution of settlement quality in the subdistric Mandiangin Koto Selayan for the medium quality of settlements are having an area of $125 \mathrm{Ha}$, the quality of bad settlements has an area of $118 \mathrm{Ha}$. The medium quality of the settlements is the most in the village Kubu Gulai Bancah while the bad quality is the most in the village Campago Guguak Bulek. (3) test image accuracy using confution matrix produce accuracy of image that is $94,73 \%$.
\end{abstract}

Keyword : quality of settlements, remote sensing, Quickbird Satellite Imagery, GIS 


\section{Pendahuluan}

Pada Undang-Undang Republik Indonesia nomor 1 tahun 2011 tentang perumahan dan permukiman arti dari permukiman adalah bagian dari lingkungan hunian yang terdiri atas lebih dari satu perumahan yang mempunyai prasarana, sarana, utilitas umum serta mempunyai penunjang kegiatan lain di kawasan permukiman.

Permukiman yang layak huni harus memiliki bangunan yang sudah permanen, lokasi yang nyaman dan akses yang lancar serta dibangun dengan material yang berkualitas baik (Nugraheni, 2013).

Permasalahan dari permukiman yang ada di Indonesia yaitu karena jumlah penduduk yang besar dan perkembangan penduduk yang sangat pesat, sehingga menyebabkan tingginya kepadatan permukiman suatu wilayah dan kepadatan permukiman sendiri bisa menjadi ukuran tingkat kekumuhan suatu permukiman atau buruknya kualitas permukiman (Judohusodo, 1991). Tingginya pertumbuhan penduduk di kota disebabkan karena kota merupakan pusat kegiatan manusia dan menawarkan banyak kesempatan yang lebih baik dari pada di daerah pedesaan. Jumlah penduduk yang tinggi membawa dampak pada kebutuhan lahan yang tinggi untuk permukiman. Jumlah penduduk yang tinggi juga menyebabkan masalah bagi pemerintah untuk melakukan pengadaan dan penataan ruang untuk permukiman, pendidikan, kesehatan dan sarana prasarana lain (Sutanto, 1981). Dalam jangka waktu yang lama kebutuhan lahan akan terus bertambah seiring meningkatnya jumlah penduduk, sedangkan ketersediaan lahan untuk permukiman relatif tetap (Sumunar, 2002). Lahan yang relatif tetap menyebabkan banyaknya hunian liar atau permukiman kumuh di perkotaan sehingga menurunkan kualitas permukiman di kota tersebut (Bintarto, 1987).

Permasalahan lain di dalam permukiman yaitu perumahan yang sudah lama dibangun saat belum adanya peraturan atau perencanaan dari pemerintah daerah, hal ini menyebabkan banyak rumah yang dibangun secara acak dan tidak beraturan. Kecamatan Mandiangin Koto Selayan merupakan kawasan yang memiliki jumlah penduduk terbanyak di antara kecamatan lainnya di Kota Bukittinggi (BPS Kota Bukittingi, 2016). Kota Bukittinggi sering mengalami bencana banjir salah satunya terjadi pada 16 April 2017, kawasan yang memiliki debit air tinggi terdapat di kawasan RT 02 RW 01 Anak Aia Kelurahan Pulai Anak Aia dengan ketinggian 30-1,5 meter, banjir terjadi jika sudah memasuki musim hujan dan berdurasi lama. Berdasarkan survei yang dilakukan oleh Pemko Bukittinggi penyebab dari banjir ini dikarenakan pendangkalan bandar dan penyempitan saluran air karena adanya pembangunan di sekitar bandar, drainase yang tidak bisa menampung kapasitas air hujan yang berlebihan hal ini merupakan salah satu permasalahan permukiman yang disebabkan oleh padatnya penduduk dan proses perencanaan yang kurang terprogram atau terencana dengan 
kurang baik. Daerah ini juga memiliki banyak rumah yang sudah dibangun bertahun - tahun yang lalu sehingga pembangunannya tidak sesuai dengan aturan pemerintah daerah (Haluan 2015).

Kualitas permukiman penduduk diartikan bahwa suatu permukiman dapat memenuhi kebutuhan hidup seseorang yang tinggal di permukiman tersebut. Kualitas permukiman berpengaruh terhadap kualitas hidup seseorang yang tinggal di kawasan permukiman tersebut. Kualitas permukiman yang buruk akan berdampak pada menurunnya tingkat kesejahteraan penduduk, maka sangat perlu dilakukan penelitian untuk mengetahui tingkat kualitas suatu permukiman.

Kemajuan teknologi informasi mempermudah kita dalam menentukan kondisi kualitas permukiman untuk perencanaan dan pengelolaan kawasan permukiman. Alternatif yang dapat digunakan untuk menentukan kualitas permukiman yaitu dengan memanfaatkan teknologi penginderaan jauh dan Sistem Informasi Geografis (Ambarasakti, 2013). Teknologi ini juga banyak digunakan oleh berbagai ilmu lain seperti kelautan, kehutanan, pertanian dan ilmu lainnya (Danoedoro, 2011). Salah satu data penginderaan jauh yang dapat digunakan untuk mengetahui kondisi kualitas permukiman adalah citra yang memiliki resolusi tinggi seperti Quickbird, Ikonos, dan Geoeye-1 (Swardhana ett al, 2015). Untuk penelitian kualitas permukiman ini digunakan Citra Quickbird, karena memiliki resolusi spasial yang sangat tinggi yaitu 2,4 meter (multispektral) dan 60 sentimeter (pankromatik) sehingga dapat menyajikan ketelitian data yang cukup akurat untuk mengidentifikasi permukiman dengan baik, seperti tata letak permukiman, kepadatan permukiman, lebar jalan masuk permukiman, kondisi jalan masuk permukiman, pohon pelindung, dan lokasi permukiman yang digunakan sebagai parameter untuk menentukan kualitas permukiman (Prasetyo, 2013).

Interpretasi parameter kualitas permukiman menggunakan Citra Quickbird dilakukan melalui 3 tahap yaitu deteksi, identifikasi dan analisis (Lillesand ett al, 2004). Ketiga tahap ini akan menentukan harkat dan skor untuk tiap parameter sehingga menghasilkan kualitas permukiman.

Berdasarkan penjelasan di atas maka penulis tertarik untuk mengangkat tema penelitian dengan judul :Klasifikasi Kualitas Permukiman Menggunakan Citra Quickbird di Kecamatan Mandiangin Koto Selayan Kota Bukittinggi.

\section{Metode Penelitian}

Metode penelitian ini yaitu kuantitatif. Penelitian ini menggunakan interpretasi citra dan sistem skoring dari parameter-parameter kualitas permukiman menggunakan software GIS. Parameter kualitas permukiman tersebut memiliki bobot yang berbedabeda tergantung seberapa besar peran parameter tersebut dalam menciptakan kekumuhan.

Data yang digunakan dalam penelitian ini yaitu peta administrasi 
Kecamatan Mandiangin Koto Selayan Kota Bukittinggi sebagai peta dasar untuk menentukan batas kawasan penelitian, data bangunan, peta jalan, peta badan jalan, peta sungai, Citra Quickbird kawasan Mandiangin Koto Selayan Kota Bukittinggi tahun 2012.

Teknik analisis data yang digunakan dalam pembuatan tujuan penelitian yaitu:

1. Parameter kualitas permukiman citra di Kecamatan Mandiangin Koto Selayan Kota Bukittinggi.

Penilaian kualitas permukiman menggunakan parameter yang bersumber dari Dirjen Cipta Karya, Dep. PU (1980). Berikut harkat dan parameter yang disadap dari citra : a. Pola Kepadatan Permukiman

Penilaian untuk penentuan kualitas kepadatan bangunan tidak berdasarkan ketentuan KDB (koefesien dasar bangunan). Perhitungan kepadatan permukiman di setiap unit permukiman dihitung dengan menggunakan rumus :

Kepadatan rumah :

$\frac{\sum \text { Seluruh Luas Atap }}{\sum \text { Luas Blok Permukiman Dalam Satuan Unit Permukiman }} \times 100 \%$

Berikut tabel kriteria kepadatan bangunan untuk menentukan harkat atau kualitas kepadatan bangunan :

Tabel 1. Klasifikasi dan harkat kepadatan bangunan

\begin{tabular}{|l|c|c|}
\hline Kriteria Kepadatan Permukiman & Harkat & Klasifikasi \\
\hline$<40 \%$; Jarang & 3 & Baik \\
\hline $40 \%-60 \%$; Sedang & 2 & Sedang \\
\hline$>60 \%$; Padat & 1 & Buruk \\
\hline
\end{tabular}

Sumber : Dikjen Cipta Karya, Dep. PU ( 1980)

\section{b. Pola Tata Letak Bangunan}

Menentukan pola tata letak bangunan dapat dilihat dari bangunan yang memiliki luas yang hampir sama, arah hadap yang sama dan mengikuti pola tertentu. Dapat dilihat pada rumus dan tabel klasifikasi pola keteraturan bangunan di bawah ini :
Tata letak bangunan :

$$
\frac{\sum \text { Bangunan yang Tertata Teratur }}{\sum \text { Luas Blok Permukiman Dalam Unit Permukiman }} \times 100 \%
$$

Berikut tabel kriteria untuk menentukan harkat atau kualitas dari pola tata letak bangunan :

Tabel 2. Klasifikasi dan harkat Tata Letak Bangunan

\begin{tabular}{|l|c|c|}
\hline \multicolumn{1}{|c|}{ Kriteria Bangunan Tata Letak } & Harkat & Klasifikasi \\
\hline $\begin{array}{l}\text { Baik, bila lebih dari atau sama dengan 50\% bangunan } \\
\text { tertata teratur }\end{array}$ & 3 & Baik \\
\hline Sedang, bila 25\%-50\% bangunan tertata teratur . & 2 & Sedang \\
\hline $\begin{array}{l}\text { Buruk, bila (<25\% ) sebagian besar bangunan kurang } \\
\text { tertata teratur. }\end{array}$ & 1 & Buruk \\
\hline
\end{tabular}

Sumber : Dikjen Cipta Karya, Dep. PU (1980) 


\section{c. Pohon Pelindung Permukiman}

Penilaian untuk menentukan kualitas pohon pelindung permukiman tidak berdasarkan ketentuan RTH (ruang terbuka hijau). Perhitungan pohon pelindung di setiap unit permukiman dihitung dengan menggunakan rumus : $\frac{\sum \text { Seluruh Luas Tutupan Lahan Pohon Pelindung }}{\sum \text { Luas Blok Permukiman }} \times 100 \%$

Berikut tabel kriteria untuk menentukan harkat atau kualitas pohon pelindung permukiman :

Tabel 3. Klasifikasi dan harkat parameter pohon pelindung

\begin{tabular}{|l|c|c|}
\hline \multicolumn{1}{|c|}{ Kriteria } & Klasifikasi & Harkat \\
\hline$>50 \%$ jalanan memiliki pohon pelindung & Baik & 3 \\
\hline $25 \%-50 \%$ jalanan memiliki pohon pelindung & Sedang & 2 \\
\hline$<25 \%$ jalanan memiliki pohon pelindung & Buruk & 1 \\
\hline
\end{tabular}

Sumber : Dikjen Cipta Karya, Dep. PU (1980)

\section{d. Lebar Jalan Permukiman}

Lebar jalan dapat diartikan sebagai lebar rerata badan jalan yang menghubungkan jalan lokal dengan jalan utama pada suatu blok unit permukiman tersebut. Berikut tabel kriteria untuk menentukan kualitas lebar jalan di satu blok permukiman :

Tabel 4. Klasifikasi dan harkat lebar jalan masuk

\begin{tabular}{|l|c|c|}
\hline \multicolumn{1}{|c|}{ Kriteria } & Klasifikasi & Harkat \\
\hline $\begin{array}{l}\text { Lebar jalan masuk rata-rata }>6 \mathrm{~m} \text { (dengan asumsi pada jalan } \\
\text { tersebut dapat dilalui dua/tiga mobil secara bebas) }\end{array}$ & Baik & 3 \\
\hline $\begin{array}{l}\text { Lebar jalan masuk rata-rata antara } 4 \mathrm{~m}-6 \mathrm{~m} \text { (dengan asumsi } \\
\text { pada jalan tersebut dapat dilalui satu/dua mobil secara bebas) }\end{array}$ & Sedang & 2 \\
\hline Lebar jalan masuk rata-rata $<4 \mathrm{~m}$ & Buruk & 1 \\
\hline
\end{tabular}

Sumber : Dikjen Cipta Karya, Dep. PU (1980)

e. Kondisi Permukaan Jalan Masuk

Kondisi permukaan jalan masuk adalah pengerasan permukaan badan jalan dengan aspal yang dibedakan atas bahan pengeras jalan tersebut (Soemarwoto, 1991) dengan memperhatikan rona pada objek yang diamati. Cara penilaian kondisi permukaan jalan masuk ke permukiman yaitu :

$$
\frac{\sum \text { Panjang Jalan yang Diperkeras }}{\sum \text { Panjang Seluruh Jalan Dalam Blok }} \times 100 \%
$$

Berikut tabel kriteria untuk menentukan kualitas kondisi jalan permukiman di dalam satu blok permukiman

Tabel 5. Klasifikasi dan harkat kondisi permukaan jalan 


\begin{tabular}{|l|c|c|}
\hline \multicolumn{1}{|c|}{ Kriteria } & Klasifikasi & Harkat \\
\hline $\begin{array}{l}>50 \% \text { panjang jalan masuk yang ada pada unit } \\
\text { permukiman diperkeras denganaspal atau semen }\end{array}$ & Baik & 3 \\
\hline $25 \%$ - 50\% sepanjang jalan masuk & Sedang & 2 \\
\hline$<25 \%$ sepanjang jalan & Buruk & 1 \\
\hline
\end{tabular}

Sumber : Dikjen Cipta Karya, Dep. PU (1980)

\section{f. Lokasi Permukiman}

Dasar dari penilaian atas parameter ini adalah atas dasar jauh dekatnya suatu unit permukiman terhadap pusat atau inti kota, dimana yang pada umumnya menjadi pusat keramaian adalah jalan utama, kawasan perdagangan, dan jasa.
Selain itu juga berkait dengan sumber polusi atau bahaya bencana. Dalam memberi nilai harkat lokasi penelitian berikut tabel kriteria untuk menentukan kualitas lokasi permukiman suatu blok permukiman

Tabel 6. Klasifikasi dan harkat lokasi permukiman

\begin{tabular}{|l|c|c|}
\hline \multicolumn{1}{|c|}{ Kriteria } & Klasifikasi & Harkat \\
\hline $\begin{array}{l}\text { Baik, bila lokasi permukiman jauh dari polusi (terminal, } \\
\text { stasiun, pabrik) atau bencana (sungai, gunung) dan masih } \\
\text { dekat dengan kota. }\end{array}$ & Baik & 3 \\
\hline $\begin{array}{l}\text { Sedang, bila lokasi permukiman tidak terpengaruh secara } \\
\text { langsung }\end{array}$ & Sedang & 2 \\
\hline $\begin{array}{l}\text { Buruk, bila lokasi permukiman dekat dengan sumber } \\
\text { polusi atau bencana }\end{array}$ & Buruk & 1 \\
\hline
\end{tabular}

Sumber : Dikjen Cipta Karya, Dep. PU ( 1980)

\section{Persebaran kelas kualitas E: Harkat kondisi jalan masuk permukiman di Kecamatan F: Harkat lokasi permukiman}

\section{Mandiangin Koto Selayan}

Penentu kelas kualitas permukiman didasarkan pada jumlah skor total. Perolehan skor total didapatkan dari hasil penjumlahan dan perkalian harkat masing-masing parameter penentu dengan faktor penimbang.

Harkat Total Citra $=(\mathrm{Ax} 3)+(\mathrm{Bx} 1)+$

$$
(\mathrm{Cx} 2)+(\mathrm{Dx} 3)+(\mathrm{Ex} 2)+(\mathrm{Fx} 2)
$$

Keterangan:

A: Harkat kepadatan permukiman

B: Harkat tata letak bangunan

C: Harkat pohon pelindung jalan

D: Harkat lebar jalan masuk
Berdasarkan pendekatan ini maka klasifikasi kualitas permukiman diperoleh dengan formula :

$$
\mathrm{Ci}=\mathrm{R}: \mathrm{K}
$$

Keterangan:

Ci: interval kelas

$\mathrm{R}$ : range (nilai ini diperoleh dari selisih skor total tertinggi- skor total terendah)

$\mathrm{K}$ : Jumlah kelas (tiga kelas tingkatan, yaitu baik, sedang dan buruk) 


\section{Uji ketelitian interpretasi citra}

Menguji ketelitian dari citra yang menghasilkan kualitas permukiman di Kecamatan Mandiangin Koto Selayan digunakan metode Confusion Matrix.

\section{Hasil Dan Pembahasan}

\section{Parameter Kualitas Permukiman}

a Kepadatan permukiman di setiap blok permukiman dihitung berdasarkan jumlah luas seluruh atap dibagi dengan luas blok permukiman dalam satuan unit permukiman. Kecamatan Mandiangin Koto Selayan ini memiliki kelas sedang dengan jumlah tertinggi yang luasnya $120 \mathrm{Ha}$.

Kepadatan dengan persentase $<40 \%$ dikarenakan jumlah bangunan yang ada di blok permukiman tersebut masih jarang, tiap blok permukiman memiliki luas yang berbeda - beda sehingga kepadatan di blok satu dan lainnya berbeda - beda. Kelurahan Puhun tembok memiliki kepadatan permukiman yang tertinggi dengan persentase $74 \%$. Kepadatan di kelurahan ini dikarenakan banyaknya jumlah bangunan, dalam satu blok permukiman rata - rata jumlah bangunan dalam satu blok berjumlah 17 rumah dalam $1 \mathrm{Ha}$ untuk kepadatan di Kelurahan Puhun tembok.
Kepadatan dengan kelas baik terbanyak juga berada di Kelurahan Puhun Tembok dengan persentase $19 \%$, di dalam blok permukiman ini terdapat 20 rumah di dalam satu blok permukiman yang luasnya $7 \mathrm{Ha}$, kepadatan dengan kelas baik dikarenakan masih banyaknya lahan sawah atau lahan kosong yang belum dibangun menjadi permukiman sehingga kepadatannya rendah. Kelurahan ini memiliki kepadatan yang tinggi karena terletak di tengah kota yang dekat dengan berbagai fasilitas seperti rumah sakit, sekolah, dan lain - lain. Kepadatan dengan kelas sedang banyak terdapat di Kelurahan Campago Ipuh dengan persentase kepadatan $51 \%$, kepadatan sedang dalam Kelurahan Campago ipuh ini memiliki jumlah bangunan sebanyak 11 bangunan dalam $1 \mathrm{Ha}$. Banyaknya kepadatan kelas rendah karena pada Kelurahan Campago Ipuh masih banyak blok permukiman yang luasnya besar dibandingkan dengan luas seluruh rumah yang dibangun di atasnya. Jarak antara satu rumah dengan rumah lain masih memilik jarak seperti adanya sedikit lahan kosong. Berikut peta kepadatan permukiman yang ada di Kecamatan Mandiangin Koto Selayan 


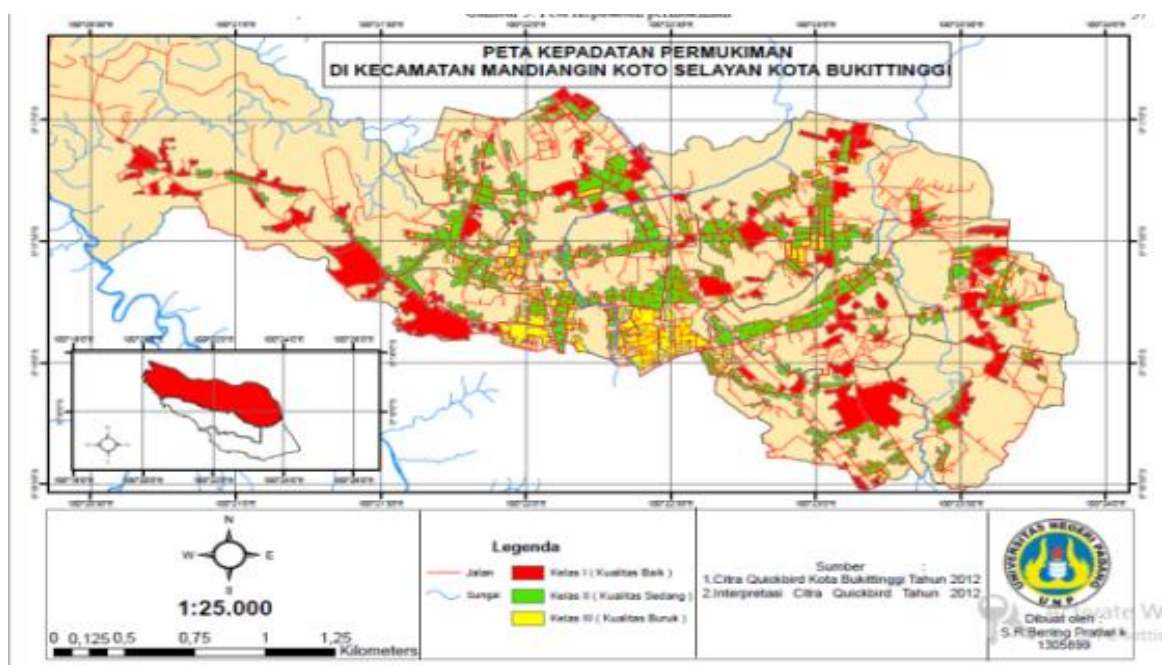

Gambar 1. Peta Kepadatan bangunan

b Kecamatan Mandiangin Koto

Selayan ini memiliki pola tata letak bangunan buruk dengan persentase tertinggi dengan luas 182 Ha.Permukiman dengan pola tata letak bangunannya memiliki persentase kelas baik tertinggi yaitu Kelurahan Garegeh dan Puhun Tembok dimana persentase keduanya $71 \%$, pola tata letak bangunan kelas baik dikarenakan banyaknya dijumpai blok permukiman yang memiliki struktur bangunan yang teratur, baik dari ukuran, posisi dan arah hadap. Di dalam kelas baik pola tata letak kelas baik memiliki banyak blok permukiman yang mengikuti pola jalan besar sehingga tertata dengan rapi dan juga banyak terdapat blok perumahan yang memiliki bentuk dan luas yang sama. Pola tata letak bangunan kelas sedang tertinggi terdapat di Kelurahan Puhun Pintu Kabun dengan persentase $41 \%$.
Pola tata letak bangunan dengan kelas sedang dikarenakan beberapa faktor seperti terdapat bangunan yang memiliki arah hadap yang sama tetapi ukuran berbeda - beda sehingga keteraturannya berkurang, begitu juga terdapat permukiman yang memiliki ukuran dan arah yang sama tetapi letaknya yang tidak tersusun dengan rapi. Kelas buruk untuk pola tata letak bangunan kelas buruk terdapat di Kelurahan Puhun Tembok dan Garegeh dengan persentase $10 \%$ hal ini dikarenakan ukuran bangunan yang berbeda beda sehingga pola di dalam blok permukiman tidak teratur. Faktor sempitnya yang digunakan untuk dibangunnya permukiman baru menyebabkan tata letak juga tidak teratur, dan juga padatnya bangunan juga membuat bangunan tidak teratur. Berikut peta pola tata letak bangunan di Kecamatan Mandiangin Koto Selayan : 


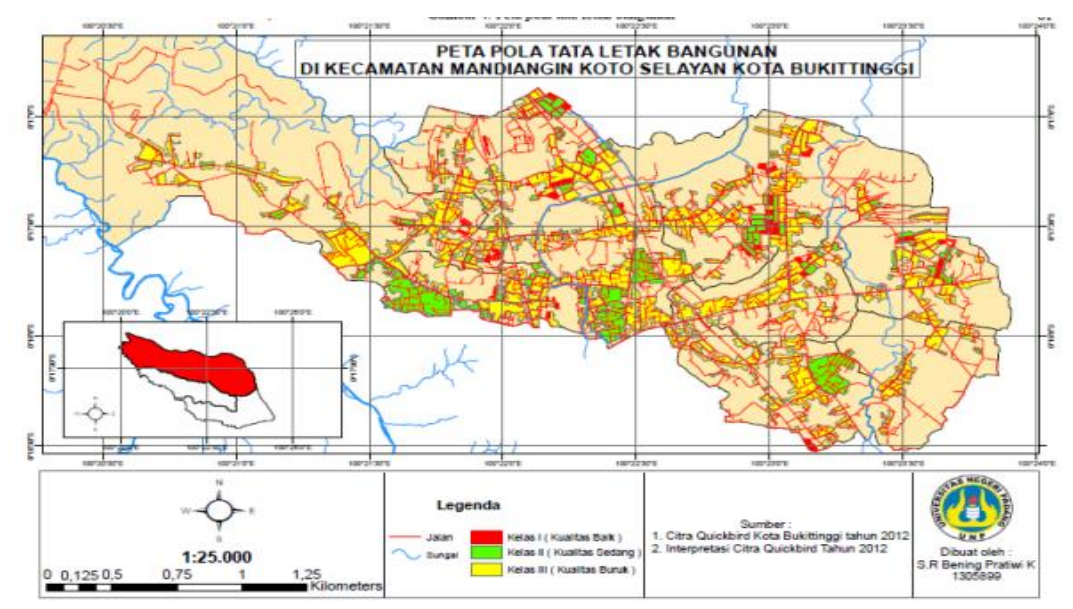

Gambar 2. Peta pola tata letak bangunan

c Kecamatan Mandiangin ini memiliki pohon pelindung kelas buruk dengan interpretasi tertinggi yang memiliki luas sebesar $233 \mathrm{Ha}$.

Permukiman dengan pohon pelindung kelas baik tertinggi terdapat di Kelurahan Puhun Tembok yaitu $64 \%$, kawasan ini memang masih banyak memiliki lahan hijau yang belum dibangun menjadi permukiman, luas blok permukiman juga hanya sebesar 0,05 Ha tetapi memilik luas pohon dengan persentase $64 \%$. Jumlah pohon yang terdapat di sisi kiri dan kanan jalan permukiman memiliki jumlah yang banyak atau memiliki ukuran kanopi yang besar sehingga memberikan suasana teduh di daerah pepohonan. Untuk pohon pelindung permukiman kelas sedang tertinggi juga terdapat di Kelurahan Puhun Tembok dengan persentase $47 \%$. Permukiman dengan kelas buruk untuk pohon pelindung permukiman tertinggi terdapat di Kelurahan Koto Selayan hal ini disebabkan jumlah pohon yang sedikit atau ukuran kanopi yang kecil. Permukiman yang padat juga membuat pohon pelindung sedikit karena tidak adanya ruang untuk menanam pohon. Berikut peta pohon pelindung permukiman di Kecamatan Mandiangin Koto Selayan : 


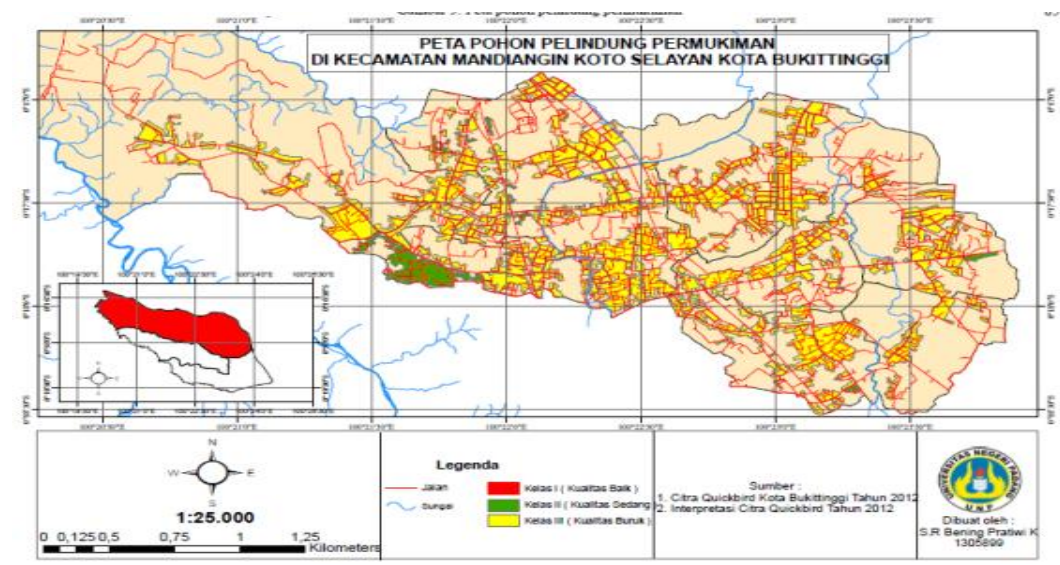

Gambar 3. Peta pohon pelindung permukiman

d Lebar jalan permukiman yang ada di Kecamatan Mandiangin Koto Selayan memiliki klasifikasi kelas buruk dengan persentasi tertinggi yang luasnya $207 \mathrm{Ha}$.

Lebar jalan permukiman dengan kelas baik terdapat lebar jalan sebesar 10 meter, faktor yang membuat permukiman ini memiliki lebar jalan > 6 meter karena permukiman yang berada di sepanjang jalan arteri primer, hal ini membuat mudahnya akses menuju permukiman tersebut. kelas sedang memiliki lebar rata rata tertinggi sebesar 5 meter, padatnya permukiman dan rumah yang cenderung memiliki jarak kecil menyebabkan lebar jalan menjadi sempit sehingga akses menjadi susah untuk memasuki permukiman menggunakan kendaraan roda 2 ataupun roda 4 . Permukiman dengan lebar jalan kelas rendah berukuran 2 meter. Berikut peta lebar jalan permukiman di Kecamatan Mandiangin Koto Selayan :

Permukiman dengan lebar jalan

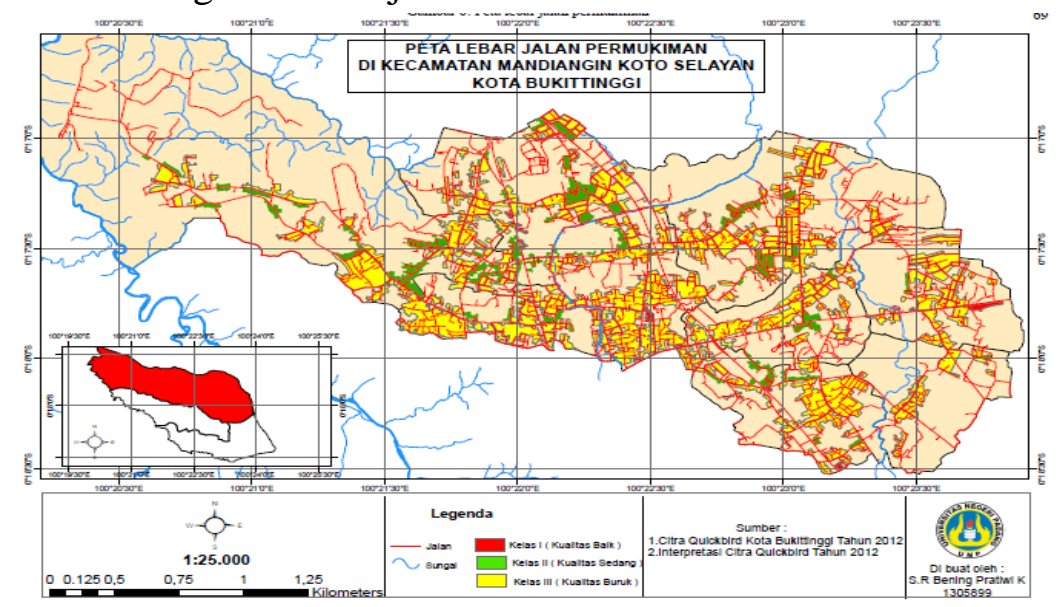

Gambar 4. Peta lebar jalan permukiman

e Kondisi jalan yang ada di permukiman

Kecamatan Mandiangin Koto Selayan ini memiliki kelas baik dengan persentasi tertinggi yang mana memiliki luas sebesar 204 Ha. Permukiman dengan kondisi jalan 
permukiman kelas baik memiliki persentase tertinggi yaitu Kelurahan Puhun Tembok dengan persentase 92 $\%$. Permukiman dengan kelas baik karena memiliki jalan yang sudah diperkeras dengan aspal ataupun semen dari keseluruhan jalan yang ada di permukiman tersebut, permukiman dengan kondisi jalan permukiman kelas baik di kelurahan Puhun Tembok ini juga dikarenakan banyaknya permukiman yang berada di sepanjang jalan besar, dan terletak di daerah yang memiliki fasilitas seperti sekolah dan rumah sakit sehingga akses harus baik. Permukiman dengan kondisi jalan kelas sedang tertinggi terdapat di Kelurahan Campago Ipuh dengan nilai $42 \%$. Permukiman dengan kondisi jalan permukiman kelas buruk dengan persentase terendah yaitu $0 \%$ terdapat di Kelurahan Manggis Ganting, Puhun Tembok, Puhun Pintu Kabun, Campago Guguak Bulek. Permukiman di kecamatan ini memiliki kelas baik yang terbanyak untuk kondisi jalan permukiman. Permukiman dengan kelas buruk atau memiliki jalan yang belum diperkeras bisa ditandai dengan rona jalan yang berwarna coklat dan jumlah perumahan yang jarang karena masih sedikit yang menempati daerah tersebut sehingga jalanan belum diperkeras oleh pemerintah menggunakan aspal ataupun semen. Berikut peta kondisi jalan permukiman di Kecamatan Mandiangin Koto Selayan :

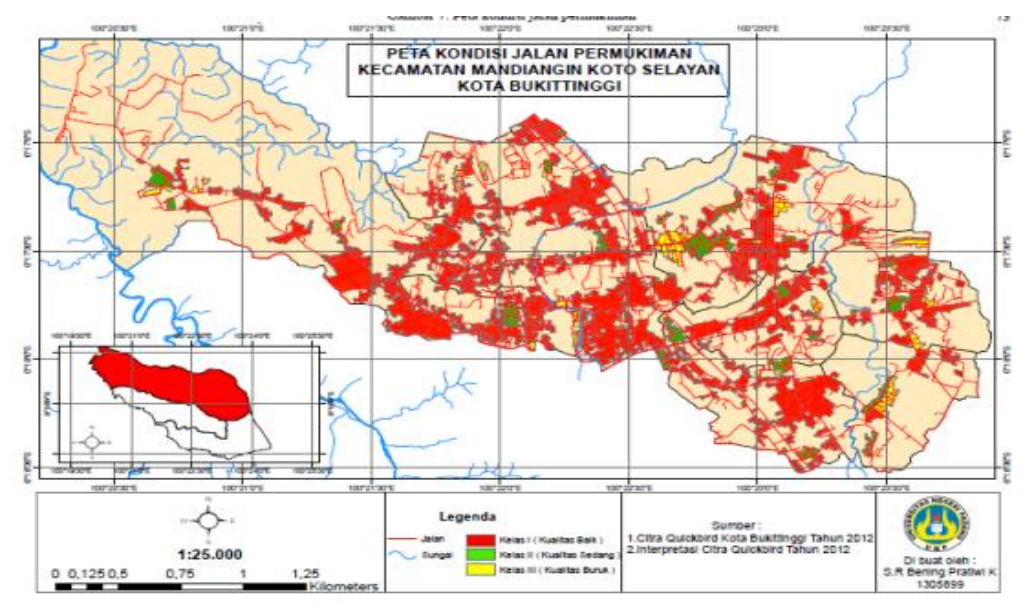

Gambar 5. Peta kondisi jalan permukiman

f Kecamatan Mandiangin Koto Selayan memiliki kualitas lokasi permukiman sedang dengan persentase tertinggi dan memiliki luas sebesar 91 Ha. Permukiman kelas baik banyak terdapat di Kelurahan Kubu Gulai Bancah dengan luas 29 Ha. Kriteria untuk permukiman dengan lokasi kelas baik dikarenakan letak blok permukimannya jauh dari polusi seperti pasar, industri, pabrik dan jauh dari sungai yang memiliki resiko banjir. Lokasi kelas baik memiliki jarak di luar 50 meter untuk sungai dan 100 meter untuk polusi. Permukiman dengan lokasi 
permukiman kelas sedang yaitu Campago Ipuh dengan luas $12 \mathrm{Ha}$ memiliki jarak yang masuk ke dalam buffer polusi dan bencana yaitu 50 25 meter untuk jarak dengan sungai dan 100-50 meter dari polusi seperti pabrik, pasar, terminal dan lain -lain.
50 meter dan < dari 25 untuk. Permukiman dengan lokasi permukiman kelas buruk banyak terdapat di Kelurahan Puhun Pintu Kabun. Berikut peta Lokasi permukiman di Kecamatan Mandiangin Koto Selayan :

Lokasi pemukiman dengan kelas buruk dikarenakan jarak yang dekat dengan polusi dan juga sungai yaitu <

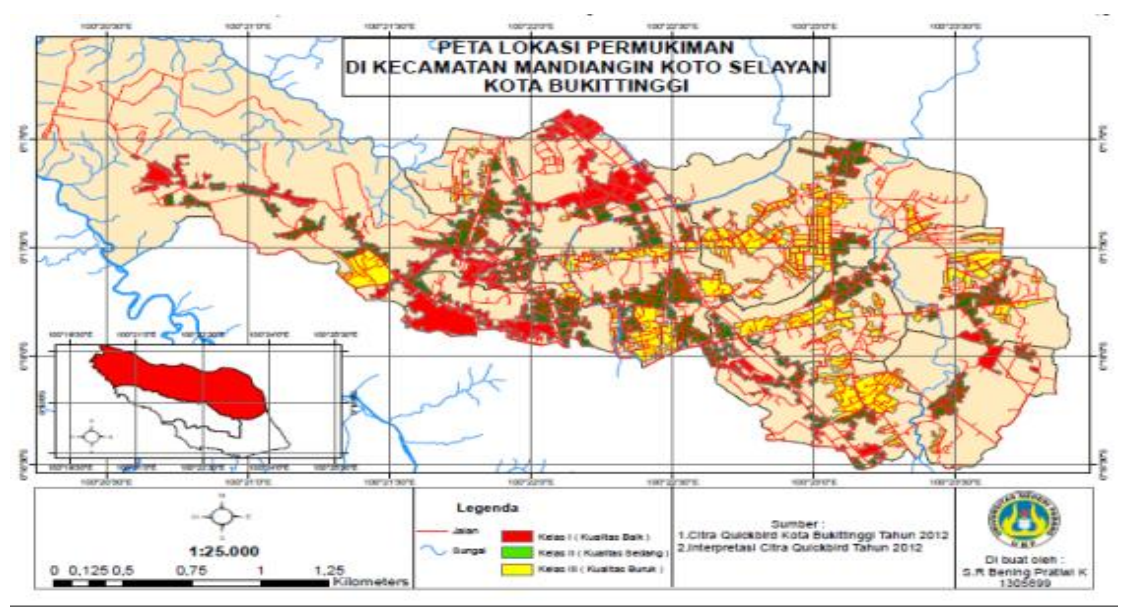

Gambar 6. Peta lokasi permukiman

\section{Persebaran}

Kualitas

\section{Permukiman di Kecamatan}

Mandingin Koto Selayan

Mendapatkan kelas kualitas permukiman dilakukan interpretasi terhadap ke 6 parameter dan melakukan sistem skoring untuk mendapatkan klasifikasi kelas yang bersumber dari Ditjen Cipta Karya Dep. PU tahun 1980 (Prasetyo, 2013). Melakukan klasifikasi kelas kualitas permukiman pada tiaptiap blok permukiman yang ada di Kecamatan Mandiangin Koto Selayan.
Persebaran kualitas permukiman di Kecamatan Mandiangin Koto Selayan ini tidak memiliki kelas baik dan memiliki kelas sedang dengan luas 125 Ha, sedangkan kelas buruk memiliki luas sebesar $118 \mathrm{Ha}$. Tiap kelurahan di Kecamatan Mandiangin Koto Selayan ini juga memiliki persebaran kelas kualitas permukiman yang berbeda beda. Berikut peta kualitas permukiman di Kecamatan Mandiangin Koto Selayan : 


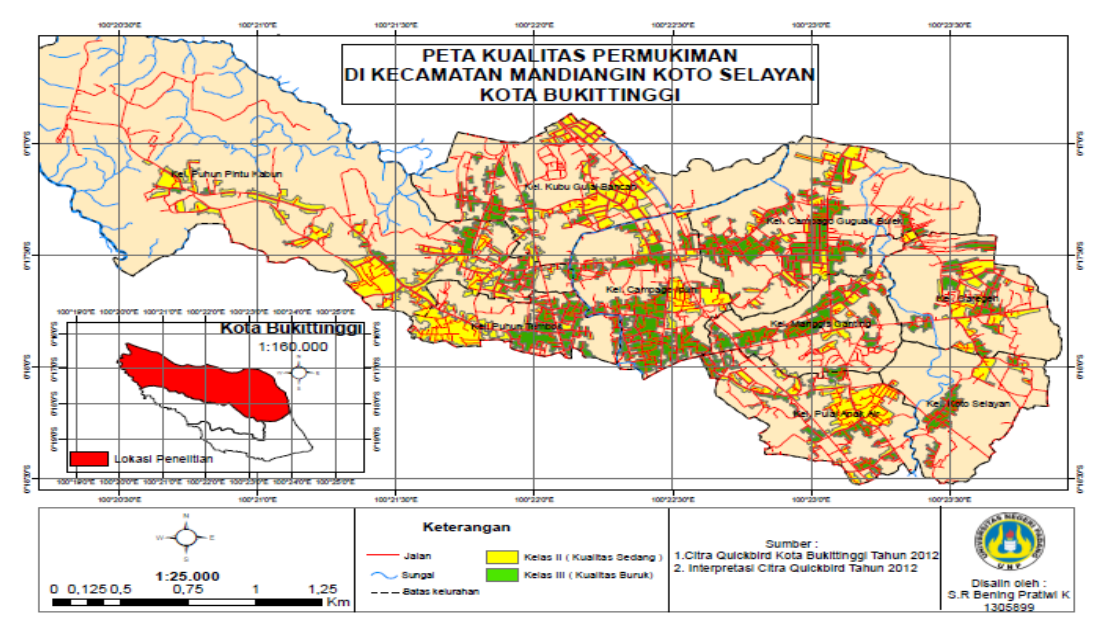

Gambar 7. Peta kualitas permukiman

Kelurahan dengan kelas kualitas permukiman sedang paling banyak yaitu Kelurahan Kubu Gulai Bancah dengan jumlah 56 blok permukiman yang luasnya $21 \mathrm{Ha}$. Kelas sedang ini memiliki pengaruh besar dari kepadatan permukiman dan lebar jalan masuk permukiman. Permukiman yang memiliki kelas sedang memiliki kepadatan yang rendah dan lebar jalan > 6 meter sudah memiliki skor 9, untuk parameter lain memiliki skor dbawah 6 . Skor dari parameter yang dimiliki kelas sedang berada diantara 23-32. Kelurahan dengan kelas kualitas permukiman buruk paling banyak yaitu Campago Guguk Bulek dengan jumlah blok 52 yang luasnya $20 \mathrm{Ha}$. Skor dari kelas kualitas permukiman kelas buruk berkisar dari 13-22. Blok permukiman yang memiliki kelas kualitas permukiman sedang dan buruk dikarenakan dari keenam parameter yang diinterpretasikan terdapat satu atau beberapa parameter yang memiliki skor rendah dan memiliki kekurangan di dalam permukimannya, ada yang kepadatan permukimannnya masuk ke dalam kelas sedang atau buruk, kurang banyak pohon untuk mengurangi polusi, letak rumah yang tidak beraturan, atau terletak di dekat industri, pasar, terminal atau sungai.

\section{Uji Ketelitian Interpretasi Citra}

Tabel confution matrix merupakan hasil klasifikasi atau pemetaan dengan dilakukan menggunakan metode short yang dimodifikasi untuk menguji ketelitian interpretasi visual.

Hasil dari klasifikasi citra tidak semua akurasinya sesuai dengan yang sebenarnya sehingga diperlukan uji akurasi dengan data yang didapat di lapangan dengan hasil klasifikasi citra. Hasil dari interpretasi citra dan dilakukan pengecekan di lapangan didapat perbedaan hasil interpretasi, dapat dilihat dari tabel di bawah ini yaitu:

Tabel 7. Uji akurasi interpretasi citra 


\begin{tabular}{|c|c|c|c|c|}
\hline \multicolumn{2}{|c|}{} & \multicolumn{2}{|c|}{ Data Lapangan } & Total Baris \\
\cline { 3 - 5 } & Sedang & Buruk & \\
\hline \multirow{2}{*}{\begin{tabular}{c} 
Hasil Interpretasi Citra \\
\cline { 3 - 5 }
\end{tabular}} & Sedang & 17 & 2 & 19 \\
\cline { 2 - 5 } & Buruk & 0 & 19 & 19 \\
\hline \multicolumn{2}{|c|}{ Total Kolom } & 17 & 21 & 38 \\
\hline
\end{tabular}

Sumber : sampel dan interpretasi citra

Akurasi ketelitian citra $=\frac{36}{38} \times 100 \%=$ $94,73 \%$

Hasil akurasi ketelitian citra menggunakan confution matrix pada sampel penelitian ini yaitu 94,73\%. Hitungan Omisi dan Komisi ketelitian citra :

$$
\begin{aligned}
& \text { Omisi }=\frac{2}{19} \times 100=10 \% \\
& =\frac{0}{19} \times 100=0 \% \\
& \text { Komisi }=\frac{0}{19} \times 100=0 \% \\
& =\frac{02}{19} \times 100=10 \%
\end{aligned}
$$

Perhitungan akurasi dengan Indeks Kappa adalah sebagai berikut :

IK

$=\frac{(38 \times 36)-(17 \times 19)+(21 \times 19)}{38^{2}-(17 \times 19)+(21 \times 19)} \times 100$

$=0,8947=89 \%$

Nilai indeks Kappa adalah 0,8947 yang berarti hasil klasifikasi tersebut mampu menghindari $89 \%$ kesalahan yang muncul. Indeks Kappa merupakan multivariansi diskrit yang digunakan untuk menentukan akurasi. Nilai kappa menunjukan konsistensi akurasi dari hasil klasifikasi.

Dari hasil uji akurasi citra ini didapatkan dua kesalahan dalam interpretasi citra di Kecamatan Mandiangin Koto Selayan ini. Kualitas dengan kelas sedang di dalam interpretasi memiliki kelas buruk saat dilakukan pengambilan data lapangan. Kesalahan ini terjadi dikarenakan saat interpretasi blok permukiman tersebut masih memiliki kepadatan bangunan yang rendah atau sedang pada tahun 2012, dan saat cek lapangan yang dilakukan pada tahun 2017 sudah ada beberapa bangunan baru yang dibangun di blok permukiman tersebut. Kesalahan pada interpretasi citra untuk pohon juga disebabkan karena bagian pohon di permukiman yang berbaur dengan semak belukar yang tinggi dan memiliki rona sama dengan pohon, juga terdapat beberapa pohon yang ukurannya sudah berbeda ataupun sudah tidak ada lagi.

\section{Simpulan}

Adapun kesimpulan dalam penelitian ini yaitu:

1. Parameter kualitas permukiman dari citra

Kepadatan bangunan memiliki kelas sedang dengan luas terbesar di kecamatan ini, untuk pola tata letak bangunan memiliki kelas buruk dengan luas terbesar, pohon pelindung permukiman memiliki kelas buruk dengan luas terbesar, lebar jalan memiliki kelas buruk dengan luas terbesar, kondisi jalan 
memiliki kelas baik dengan luas terbesar, dan parameter lokasi permukiman memiliki kelas sedang dengan luas terbanyak yang ada di Kecamatan Mandiangin Koto Selayan.

2. Persebaran kualitas permukiman di Kecamatan Mandiangin Koto Selayan untuk kualitas permukiman sedang memiliki luas $125 \mathrm{Ha}$, sedangkan kualitas permukiman buruk memiliki luas 118 Ha. Kualitas permukiman kelas sedang paling banyak di Kelurahan Kubu Gulai Bancah sedangkan kualitas permukiman kelas buruk paling banyak di Kelurahan Campago Guguak Bulek.

3. Uji ketelitian citra dengan membandingkan hasil interpretasi citra dan data lapangan yang didapatkan menggunakan confution matrix menghasilkan nilai akurasi ketelitian citra yaitu 94,73\%. Nilai omisi untuk uji ketelitian ini yaitu $10 \%$ dan komisi $0 \%$. Nilai indeks kappa adalah 0,8947 yang berarti hasil klasifikasi tersebut mampu menghindari $89 \%$ kesalahan yang muncul.

\section{Saran}

Adapun saran dalam penelitian ini yaitu:

1. Perlu lebih banyaknya turun tangan pemerintah dan masyarakat untuk peduli terhadap permukiman karena kecamatan ini sudah mengalami permasalahan kualitas seperti banjir.

2. Beberapa parameter memiliki kelas kualitas buruk dengan persentase tertinggi seperti pola tata letak bangunan, pohon pelindung di permukiman, lebar jalan dan lokasi yang terpengaruh langsung dengan polusi. Hal ini seharusnya menjadi panduan pemerintah untuk lebih memperhatikan parameter tersebut dan mencari jalan keluar agar kualitasnya lebih baik.

3. Pemerintah sebaiknya memperhatikan bagian kualitas yang kurang baik agar kualitas permukiman kelas baik bisa merata di seluruh Kecamatan Mandiangin Koto Selayan.

\section{Daftar Rujukan}

Ambarasakti, G.Y. 2013. Analisis Kualitas Lingkungan Permukiman dengan menggunakan aplikasi citra penginderaan jauh tahun 2006 dan 2010 di Kecamatan Sewon Kabupaten Bantul. Universitas Muhamadyah Surakarta . Yogyakarta.

Badan Pusat Statistik Kota Bukittinggi. (2016). Bukittinggi Dalam Angka 2016. Bukittinggi : Badan Pusat Statistik.

Bintarto. 1987. Pola kota dan permasalahannya. Universitas Gajah Mada. Yogyakarta.

Danoedoro, Projo. (2011). Pengantar Penginderaan Jauh Digital. Yogyakarta: ANDI Offset. 
Haluan News.(2015, 16 April). Saat Warga Bukittinggi Menghadapi Banjir.https://harianhaluan.com/mobile/detailberita/44845/saat-wrgabukittinggi-menghadapi-banjir.html. (diakses 5 Maret 2018)

Judohusodo. 1991. Timbulnya permukiman liar di daerah perkotaan. Jurnal ilmu sosial No 1. 1-5. Gramedia. Jakarta.

Lillesand, T.M and R.W. Kiefer. Penginderaan jauh dan interpretasi citra. Terjemahan. 2014. Gajah Mada University Press. Yogyakarta.

Nugraheni, T. 2013. Analisis Kualitas Lingkungan Permukiman Menggunakan Citra Quickbird Di Kecamatan Kota Gede.100-102. Surakarta : Universitas Muhamadiyah.

Prasetyo, W.T. 2013. Kajian Kualitas Permukiman Dengan Citra Quickbird Dan Sig Di Kecamatan Serengan. 296-297. Surakarta : Universitas Diponegoro.

Sumunar, D.R.S. 2002. Kajian kualitas lingkungan permukiman Kota Yogyakarta bagian selatan dengan foto udara pankromatik hitam putih dan SIG. Universitas Negeri Yogyakarta. Yogyakarta.

Sutanto. 1981. Penginderaan Jauh untuk penggunaan lahan urban. PUSPIC. UGM. Yogyakarta.

Soemarwoto, otto. 1991. Analisis Dampak Lingkungan. Gajah Mada University Press. Yogyakarta.

Swardhana, Laila, Nurma, Andhika dan Widya. 2015. Pemanfaatan Citra Quickbird dan SIG untuk pemetaan tingkat kualitas permukiman. Universitas Gajah Mada. Yogyakarta.

Undang - Undang No 1 Tahun 2011 tentang Perumahan dan Kawasan Permukiman 2011. Sekertariat Negara. Jakarta. 